\title{
Study Habits of Secondary School Students of Working and Non- Working Mothers
}

\author{
Dr. Chandana Aditya ${ }^{1}$ Prof. Radha Ghosh ${ }^{2}$
}

\begin{abstract}
This research aims to explore reading habits of secondary school students of working and nonworking mothers. Furthermore an attempt has been made to see whether any difference exists between their reading habits in different environments considering seven domains using a standard study habit inventory. The sample included total 45 students of secondary groups comprising working and non-working mothers.

The data was collected and analysed on the basis of methodology described in details in this project. The main objective is to ear mark the problem areas and environments mostly affect the study habits of secondary students. The study will help to identify the domain and an early intervention can help the students to improve their study habits for better performance and to improve their academic achievements.
\end{abstract}

Key words: Mothers, non working, study habits, working

\section{Introduction}

Education has become the right of every child. Learning style differs from person to person. Some of us receive information better where as others prefer an environment that has the least visual distraction. However, we learn what should be learnt successfully.

It is important that the students should become independent learners, which help them to apply learnt skills as well as to prepare themselves for the examinations. Learning becomes fruitful when students use what they have learnt effectively and contextually. Students need to have appropriate independent study habits for mastering school subjects.

According to Good [1] (1973) the term study habits is "the students' way of study whether systematic, efficient or inefficient etc."

A child's earliest education is received in a family and basic ideas are initiated which determine his/her later all round development in school and outside home. The role of mother in the development of child is very vital in a family and the mother acts as a model and influence the child's growth and behaviour. In general, mother is more influential than father to discipline the child in behaviour, study habits, attitude and guides towards a career.

In the modern society most of the family is a nuclear one and like western countries both the parents are working. Women employment rate has increased very rapidly in India resulting changes in the structure and function of family. Children whose mother is working grow in a different environment as compared to those of non-working mother. Differences in the family environment have great impact on individuals' study habit.

\section{Review of literature}

Good study habits lead to good academic record and bad study-habits lead to poor academic record as there is direct relationship between study habits and academic achievement. Study habits play an important role in human performance in academic field (Verma, 1996[2]; Verma \& Kumar, 1999[3]; Satapathy \& Singhal, 2000[4]; Vyas, 2002[5]).

The nature of the family has significant influence on the study habits of students with respect to preparation for examination and school environment (Rajendran et al., 2009[6]).

The proposed topic has been selected to analyse the study habits of secondary students pertaining to working and Non-working mothers as the ratio of working mother is gradually growing up in India. Secondly, the home environment is totally different in both the cases which creates different study environment. The proposed study will help to draw a guideline for the early intervention and corrective measure for better study habit as well as overall performance of the student.

Study habits somehow interrelate with good habits which are very important for the acquisition of knowledge. In order to study effectively, it is not only necessary for the students to be interested in the subjects of study, but also to possess the knowledge and effective methods of study. This is the reason why the author

\footnotetext{
${ }^{1}$ Lecturer, Dept of Psychology, Bijoy Krishna Girls' College, Howrah,

${ }^{2}$ Assistant Professor, Dept of Education, Bijoy Krishna Girls' College, Howrah, India
} 
feels that the study habits of secondary standard students is very much important as better study habits will lead to better performance and choice of career after class-XII.

\section{Objectives}

Objectives of the study is to analyse the differences in the study habits of secondary students belonging to working mothers and Non-working mothers on the following domain / areas 1)Home environment and planning 2)Reading and note taking 3)Planning of subjects 4)Habit of Concentration 5)Preparation for Exam 6)Habits and Attitudes 7)School environment

\section{Hypotheses}

H01. There will be no significant difference between students of working and non-working mothers on the total study habits of secondary group.

H02. There will be no significant difference between students of working and non-working mothers on the domain "Home environment and planning of work".

H03. There will be no significant difference between students of working and non-working mothers on the domain "Reading and note taking".

H04. There will be no significant difference between students of working and non-working mothers on the domain "Planning of subjects".

H05. There will be no significant difference between students of working and non-working mothers on the domain "Concentration".

H06. There will be no significant difference between students of working and non-working mothers on the domain "Preparation of the exam".

H07. There will be no significant difference between students of working and non-working mothers on the domain "Habits and Interest".

H08. There will be no significant difference between students of working and non-working mothers on the domain "School environment".

\section{Methodology}

The study is conducted on a sample of 45 students consisting of 20 students of working mother and 25 students of non-working mothers of the age group 16 to 18 , studying in secondary section collected from a Govt. Co-education School. The selective sample of 45 students of working and non-working mothers was selected using simple random sampling technique from class XII.

\section{Tests / Tools}

Study Habits Inventory constructed by Dr. B.V. Patel (1975) has been used to measure the study habits of students. The tool consists of 45 items distributed in seven different domains / areas mentioned in the objective. There are five point scale ("Always", "Often", "Sometimes", "Seldom" and "Never"). The inventory is also listed in the National Library of Educational \& Psychological Test (NLEPT) catalogue published by NCERT.

\section{Statistics used}

The collected data has been evaluated and scored as per the manual of the inventory used. The analysis has been done by applying Mean, S.D and t-ratio as per statistical analysis methods.

\section{Result and discussion}

Table 1: Mean and Standard deviation values of each domain of Study Habit Inventory and 't' values for each domain for working and non working mothers

\begin{tabular}{|c|c|c|c|c|c|c|}
\hline $\begin{array}{l}\text { Domains of } \\
\text { Study Habits } \\
\text { Inventory }\end{array}$ & Groups & $\begin{array}{l}\text { No. of } \\
\text { Samples }\end{array}$ & Mean & SD & t-Value & $\begin{array}{l}\text { Level of } \\
\text { Significance }\end{array}$ \\
\hline \multirow{2}{*}{$\begin{array}{l}\text { Home } \\
\text { Environment } \\
\text { \& Planning } \\
\text { (D1) }\end{array}$} & $\begin{array}{l}\text { Working } \\
\text { Mothers }\end{array}$ & 20 & 19 & 3.30 & 3.73 & \multirow[t]{2}{*}{$\begin{array}{l}\text { Significant at } \\
0.01 \text { Level }\end{array}$} \\
\hline & $\begin{array}{l}\text { Non- } \\
\text { Working } \\
\text { Mothers } \\
\end{array}$ & 25 & 22 & 4.63 & & \\
\hline \multirow{3}{*}{$\begin{array}{l}\text { Reading and } \\
\text { Note Taking } \\
\text { (D2) }\end{array}$} & $\begin{array}{l}\text { Working } \\
\text { Mothers }\end{array}$ & 20 & 34 & 5.23 & 1.03 & \multirow[t]{2}{*}{ Not Significant } \\
\hline & $\begin{array}{l}\text { Non } \\
\text { working } \\
\text { mother } \\
\end{array}$ & 25 & 20 & 4.45 & & \\
\hline & & & & & & \\
\hline
\end{tabular}




\begin{tabular}{|c|c|c|c|c|c|c|}
\hline \multirow{2}{*}{$\begin{array}{l}\text { Planning of } \\
\text { Subjects } \\
\text { (D3) }\end{array}$} & $\begin{array}{l}\text { Working } \\
\text { Mothers }\end{array}$ & 20 & 18.5 & 4.5 & 0.36 & Not Significant \\
\hline & $\begin{array}{l}\text { Non- } \\
\text { Working } \\
\text { Mothers }\end{array}$ & 25 & 18 & 4.69 & & \\
\hline \multirow{2}{*}{$\begin{array}{l}\text { Habit of } \\
\text { Concentration } \\
\text { (D4) }\end{array}$} & $\begin{array}{l}\text { Working } \\
\text { Mothers }\end{array}$ & 20 & 11 & 2.2 & 1.13 & \multirow[t]{2}{*}{ Not Significant } \\
\hline & $\begin{array}{l}\text { Non- } \\
\text { Working } \\
\text { Mothers }\end{array}$ & 25 & 12 & 3.42 & & \\
\hline \multirow{2}{*}{$\begin{array}{l}\text { Preparation } \\
\text { for } \\
\text { Examination } \\
\text { (D5) }\end{array}$} & $\begin{array}{l}\text { Working } \\
\text { Mothers }\end{array}$ & 20 & 23 & 3.86 & 2.37 & \multirow[t]{2}{*}{$\begin{array}{l}\text { Significant at } \\
0.05 \text { Level }\end{array}$} \\
\hline & $\begin{array}{l}\text { Non- } \\
\text { Working } \\
\text { Mothers } \\
\end{array}$ & 25 & 20 & 4.46 & & \\
\hline \multirow{2}{*}{$\begin{array}{l}\text { Habits and } \\
\text { Attitudes } \\
\text { (D6) }\end{array}$} & $\begin{array}{l}\text { Working } \\
\text { Mothers }\end{array}$ & 20 & 24 & 3.84 & 2.91 & \multirow[t]{2}{*}{$\begin{array}{l}\text { Significant at } \\
0.01 \text { Level }\end{array}$} \\
\hline & $\begin{array}{l}\text { Non- } \\
\text { Working } \\
\text { Mothers }\end{array}$ & 25 & 27 & 6.11 & & \\
\hline \multirow{2}{*}{$\begin{array}{l}\text { School } \\
\text { Environment } \\
\text { (D7) }\end{array}$} & $\begin{array}{l}\text { Working } \\
\text { Mothers }\end{array}$ & 20 & 17.5 & 2.16 & 0.36 & \multirow[t]{2}{*}{ Not Significant } \\
\hline & $\begin{array}{l}\text { Non- } \\
\text { Working } \\
\text { Mothers } \\
\end{array}$ & 25 & 18 & 5.88 & & \\
\hline \multirow[t]{2}{*}{ Total } & $\begin{array}{l}\text { Working } \\
\text { Mothers }\end{array}$ & 20 & 147 & 14.71 & 0.28 & \multirow[t]{2}{*}{ Not significant } \\
\hline & $\begin{array}{l}\text { Non- } \\
\text { Working } \\
\text { Mothers }\end{array}$ & 25 & 149 & 28.94 & & \\
\hline
\end{tabular}

From the summary table of result, it is found that there is significant difference between wards of working and non-working mothers on the measures of domain area Home Environment \& Planning (D1) at 0.01 level of confidence interval. Similarly this table shows that there is significant difference between wards of working and non-working mothers on the measures of domain area Preparation for Examination (D5) at 0.05 level of confidence. One more domain Habits and Attitudes (D6) shows that there is significant difference between wards of working and non-working mothers at 0.01 level of confidence. Other four domain areas i.e Reading and Note Taking (D2), Planning of Subjects (D3), Habit of Concentration (D4) and School Environment (D7) where the t-values are 1.03, $0.36,1.13$ and 0.36 respectively show no significant differences between wards of working and non-working mothers. Regarding the total study habits the mean score of wards of working and non-working mothers group are found to be 147 and 149 respectively where as their corresponding SDs are 14.71 and 28.94 respectively. When the t-values are calculated to find out the significant difference between the means of two groups the values comes as 0.36 , which is not significant.

\section{Conclusion}

The study implies that although there is no significant difference in total study habits between students of working mother and students of non-working mothers. However, from the study it is evident that maternal employment has significant effect on some areas of study habits like Home Environment \& Planning $(0.01$ level), Preparation for Examination (0.05level) and Habits and Attitudes (0.01 level). The higher mean score shows that Home environment \& Planning of students of non-working mothers are better than the students of working mothers. In same way, it is evident that Preparation for Examination of students of working mothers is better than the students of non-working mothers. It is also evident from the means, that Habits and Attitudes of students of non-working mothers are better than the students of working mothers.

The findings of the present study are partly agreed with the earlier findings of Sharma (1986)[7], Harwod \& Feruson (2000)[8], Akhani et al (1999)[9] and Attri (2013)[10] who reported that some of the areas of the study habits are affected by maternal employment and some areas are not.

\section{Reference}

[1]. Good, C.V. (1973), Dictionary of Education (3 ${ }^{\text {rd }}$ Ed.), McGraw Hill Book Company, New York.

[2]. Verma B.P (1996); Study habits, Locus of control and academic performance; Indian journal of psychometry and education, 27 (1), $1-6$.

[3]. Verma S and R. Kumar (1999); A correlation study between study habits and achievements in different school courses; Indian journal of psychometry and education, 30 (1), 53-56. 
[4]. Satapathy, S. and S. Singhal (2000). Mental Health of Visually and Hearing Impaired Adolescents. Journal of Personality and Clinical Studies, 16 (2), 119-127.

[5]. Vyas, A. (2002). A Study of Learning Style, Mental Ability, Academic Performance and other Ecological Correlates of Undergraduate Adolescent girls of Rajasthan. Ph.D. Thesis in Education, Meerut: Ch. Charan Singh University.

[6]. Rajendran, S., Raji, A., Sumathi, P., Rosaly, A. and Sahayaraj, W. (2009). Are Study Habits Gender Biased? Edutracks, 8(9), 41-44.

[7]. Sharma, R. (1986). A Comparative Study of the Children of the Working and Non-Working Mothers: A Psychological Study (Unpublished doctorial thesis). M.Sukh University.

[8]. Harwod, J.L. \& Ferguson, D.M. (2000). A longitudinal study of maternal labour force participation and child academic achievement. Retrieved from psychological Abstract, 2000, 84.

[9]. Akhani P, Rathi N \& Jasore M (1999). Academic achievement, study habit and loneliness of children of employed and unemployed mothers. Journal of Psychometry and Education, 30 (1), 65-57.

[10]. Attri, A.K. (2013). Study Habits of Senior Secondary Students of Working and Non-working Mothers. International Educational EJournal, \{Quarterly\}, ISSN 2277-2456, Vol-II, Issue-IV, Oct-Nov-Dec. 